DOI: http://dx.doi.org/10.18203/2320-1770.ijrcog20162154

\title{
A rare case of term viable abdominal pregnancy
}

\section{Aarushi Chaudhary*, Sarvottma Antil}

Department of Obstetrics and Gynaecology, Kalpana Chawla, Government Medical College, Karnal, Haryana, India

Received: 13 May 2016

Revised: 04 June 2016

Accepted: 07 June 2016

\section{*Correspondence:}

Dr. Aarushi Chaudhary,

E-mail: prof.aarushi@gmail.com

Copyright: () the author(s), publisher and licensee Medip Academy. This is an open-access article distributed under the terms of the Creative Commons Attribution Non-Commercial License, which permits unrestricted non-commercial use, distribution, and reproduction in any medium, provided the original work is properly cited.

\begin{abstract}
Abdominal pregnancy is a rare event, but the one that represents a grave risk to the health of the pregnant woman. An abdominal pregnancy is defined as an ectopic pregnancy that implants in the peritoneal cavity. Advanced abdominal pregnancy is a rare event with high fetal and maternal morbidity and mortality. Abdominal pregnancy is exclusive of tubal, ovarian or intra-ligamentary pregnancy. Few cases have been reported in literature so far. Here is a case of undiagnosed abdominal pregnancy surviving up to term with successful fetomaternal outcome, complications encountered during its management, role of ultrasound and MRI for same.
\end{abstract}

Keywords: Abdominal pregnancy, Diagnosis and management, Complications, Role of ultrasound

\section{INTRODUCTION}

Abdominal pregnancy is a rare event, but the one that represents a grave risk to the health of the pregnant woman. An abdominal pregnancy is defined as an ectopic pregnancy that implants in the peritoneal cavity. Advanced abdominal pregnancy is a rare event with high fetal and maternal morbidity and mortality abdominal pregnancy is exclusive of tubal, ovarian or intraligamentary pregnancy. ${ }^{1}$

\section{CASE REPORT}

23 year old female, G2P1L1 with previous normal vaginal delivery 5 years back, male baby alive and healthy, LMP 22 March 2015 and EDD 29 December 2015 at 40 weeks 3 days POG, planned for elective.

LSCS in view of anhydramnios. On GPE, patient was conscious oriented to time place person. BP 130/84 PR 94/minutes, a febrile, pallor present. Chest, CVS, CNS examination unremarkable. Per abdomen examination fetus is term size, cephalic presentation, FHS 144 bpm but localised with difficulty along right spinoumbilical line, uterus is relaxed. On PV examination Os is closed, unaffected, soft, and central.

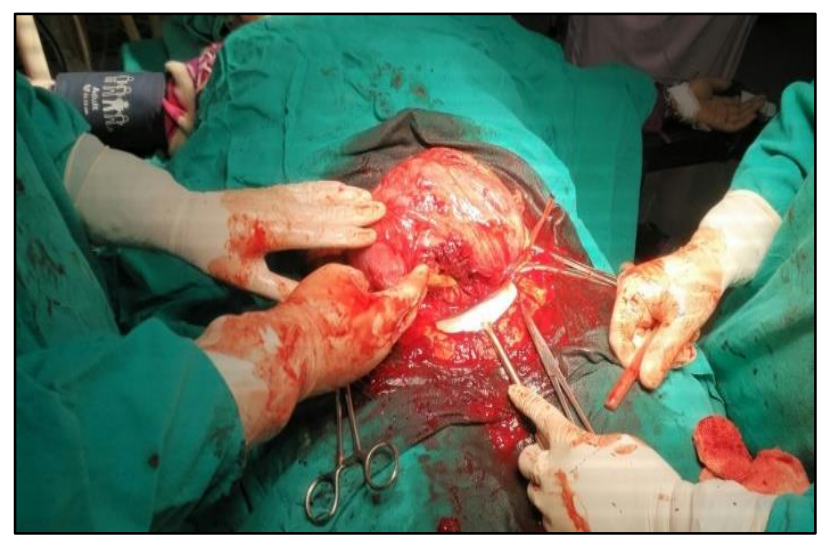

Figure 1: Pseudosac noted separate from 8 weeks sized uterus lying laterally. 
First ANC ultrasound done on 30 May 2015 showed single intrauterine gestational sac 9 weeks 5 days, CRL $29.2 \mathrm{~mm}$. Second ultrasound done on 22 July 2015 showed SLF, unstable presentation 18 weeks 2 days POG, placenta anterior in lower uterine segment reaching up to internal Os, liquor adequate. Third ultrasound done on 5 November 2015 showed SLF, cephalic presentation, placenta posterior lying in mid uterine segment, 32 weeks 6 days pog, liquor adequate clear. $4^{\text {th }}$ ultrasound done on 1 January 2016 showed SLF 38 weeks 2 days POG, cephalic (ROA), liquor negligible, placenta anterior grade 2 maturity, no e/o previa. No e/o retroplacental clot. Fetal stomach fluid filled, bladder not visualized.

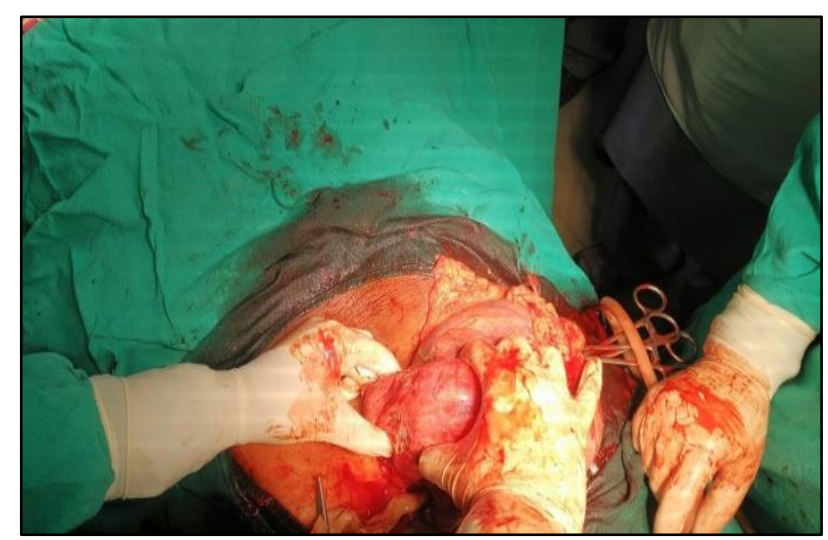

Figure 2: Pseudosac plastered to large bowel and omentum posteriorly and to left lateral pelvic wall.

Elective LSCS was done for her on 1 January 2016. Per operative findings: lower uterine segment not formed, tortuous dilated vessels noted, incised, a live male baby delivered at 1:20 pm with weight $2.5 \mathrm{~kg}$, liquor meconium stained, cord clamped and cut, baby handed over to paediatrician, APGAR score noted 9, 9.9. No spontaneous placental separation. On attempting to remove placenta manually, the same seen adherent to uterus and seen extending in left broad ligament, left tube, ovary buried into it and posteriorly attached to colon. Forming a Huge Mass? pseudosac. 8 Weeks uterus noted separate from this mass, deviated to right side with no e/o rupture or perforation. Sensing trouble at Kalpana Chawla hospital, Karnal due to lack of expert team, decision to pack and refer to tertiary care set up taken, haemostasis attained. One PRBC given per operatively.

At tertiary care institute, laparotomy with pseudosac excision with left salpingoophorectomy done. Peroperatively: pseudosac found adherent to uterus laterally, posteriorly to bowel and to left lateral pelvic wall. Same dissected from uterus, bowel and lateral pelvic wall. Placenta, left tube, ovary removed en masse with 1-2 $\mathrm{cm}$ of pseudosac attached to POD was left in Situ.

Post-operatively Patient developed fever on day 3 and day 6, Managed on injection antibiotics. Patient afebrile for 72 hours before discharge. Stitch removal done on day 14, Patient on follow up at Kalpana Chawla hospital.

HPE report s/o ectopic gestations (placental tissue with tube) sections show presence of hyalinised chorionic villi with large areas of haemorrhage, fibrin deposition and infarction. Sections from fragmented tissue reveal placental tissue adherent to fallopian tube wall. Underlying fallopian tube shows gestational changes with marked edema. No ovarian tissue identified in 8 sections.

\section{DISCUSSION}

Abdominal pregnancies are rare with incidence of only 1 in 10,000 births. A mother is 89.8 times more likely to die due to an extrauterine pregnancy versus a normal intrauterine pregnancy. ${ }^{2}$

It is difficult to detect an abdominal pregnancy early; the diagnosis is usually based on abdominal pain or emergency bleeding caused by abdominal pregnancy rupture. $^{2}$

While early in pregnancy, sonography is very useful in identification of an abdominal pregnancy, it is very difficult to make the diagnosis at a later gestational age due to inability to image the fetus in relation to the whole placenta and the uterine wall. ${ }^{2}$

An MRI however has an additional advantage of detailing vascular and placental organ invasion. ${ }^{2}$ Placental implantation site is the most life threatening complication during laparotomy. The decision to remove the placenta or not can be a determining factor for survival and this decision is subject to surgeons expertise. ${ }^{3}$

During present times, when we are aware of very high morbidity and mortality due to abdominal pregnancy, we should be able to choose which patients need to deliver at secondary health center and which patients need timely referral to tertiary care institute in ANC period. Every patient should get an opportunity for safe delivery. Only way by which abdominal pregnancy can be diagnosed is a good quality ultrasound at $6-8$ weeks POG with plates provided to every gynaecologists.

This case illustrates a rare obstetric condition which can cause a catastrophy leading to maternal morbidity and mortality. Timely antenatal diagnoses with multispeciality approach at the time of surgery at a tertiary care set up are hallmarks for the management of secondary abdominal pregnancy.

\section{CONCLUSION}

Skills training in obstetric ultrasound and in the clinical assessment of obstetric patients should emphasize features suggestive of abdominal pregnancy. This will improve diagnosis, ensure appropriate management and minimise complications. ${ }^{4}$ 
Funding: No funding sources

Conflict of interest: None declared

Ethical approval: Not required

\section{REFERENCES}

1. Amritha B, Sumangali T, Priya B, Deepak S, Sharadha R. A rare case of term viable secondary abdominal pregnancy following rupture of a rudimentary horn: a case report. J Med Case Reports. 2009;3:38.
2. Refroe S, Dajani NK, Pandey T, Magann EF. Role of serial MRI assessment in the management of an abdominal pregnancy. BMJ Case Rep. 2013:bcr2013200495.

3. Baffoe P, Fofie C, Gandau BN. Abdominal pregnancy with a healthy newborn: a case report. Ghana med J. 2011;45(2);81-3.

4. Nassali MN, Benti TM, Ntsabele MB, Musinguzi E. A case report of an asymptomatic late term abdominal pregnancy with a live birth at 41 weeks of gestation. BMC Res Notes. 2016;9:31.

Cite this article as: Chaudhary A, Antil S. A rare case of term viable abdominal pregnancy. Int $\mathbf{J}$ Reprod Contracept Obstet Gynecol 2016;5:2470-2. 